\title{
The Effects of Explicit/Implicit Instructions on the Development of Advanced EFL Learners' Pragmatic Knowledge of English: Apology Speech Act
}

\author{
Pasand Shark \\ Istanbul Aydin University, Turkey
}

\begin{abstract}
The current study explored the effects of explicit and implicit instructions on the development of advanced EFL learners' pragmatic knowledge in terms of apology speech act. A total of 10 English native speakers and 40 advanced EFL students participated in this study. The Iraqi Kurdish EFL learners were selected from grade 12 in British International School in Erbil/ Iraq and their level was determined by Oxford Quick Placement Test (OQPT) proficiency test. These 40 participants were divided randomly into two; explicit group (EG) and implicit group (IG) Later, they were provided a Multiple-choice Discourse Completion Test (MDCT) as a pre-test, which consisted of 10 different situations of apology and were based on the participants' real-life situation, each situation included 3 options and only one answer could be selected which considered to be the most appropriate answer to them. The aim was to show if there were any significant differences between EG and IG. The English native speakers were given the same (MDCT) and were asked to choose the most appropriate answers. After the treatment, (EG) and (IG) were provided the same MDCT as a post-test. The findings revealed that the results of EG and IG were significant and they showed improvements after the treatment, and the EG outperformed the IG in post-test and delayed-test.
\end{abstract}

Index Terms-pragmatic knowledge, speech acts, apology speech act, explicit/implicit teaching of pragmatic knowledge

\section{INTRODUCTION}

Pragmatic competence is an important element of communicative competence, so as EFL use their target language properly, they need to be familiarized with pragmatics. It assists the speakers know the conditions that make the utterances acceptable in some situations. Pragmatics is about the speaker's language, how the language is uttered by the speaker through communication and how the meaning (which is related to the speaker's point of view) is understood by the listener.

Moreover, apology speech act is different from any other speech act, since it is not easy to be performed and EFL learners need to recognize the strategies of apology speech act so as to develop their pragmatic knowledge and perform an appropriate expression of apology according to the situation. For example, according to Blum-Kulka, House \& Kasper (1989) apology is the most difficult speech act, therefore it has the most complex classifiable speech act because it may perform other various speech acts such as (offer, request, command... etc.) while using it. The apologizer needs to be polite, express feelings and admit of the mistake he/she has done so as to make things right. Furthermore, apology expressions are a part of expressive speech act where utterers try to point out their state or attitude, and as an apology expression needs to be effective, it should reflect real emotions (Bataineh \& Bataineh, 2006).

For the last decade studies have been conducted regarding the role of instruction in pragmatic development, the findings have indicated that using only textbook does not provide enough pragmatic knowledge also time to the learners to practice, but the students who acknowledged different aspects of pragmatic instructions were distinctive (Rose and Ng Kwai-Fun, 2001; Dastjerdi \& Rezvani, 2010; Malaz, Rabiee \& Ketabi, 2011; \& Sadeghi \& Foutooh, 2012).

Recently, various studies have been conducted regarding L2 and EFL learners' speech acts and different techniques have been used to teach them. One of the effective techniques is 'explicit and implicit' instruction to investigate or compare the effectiveness of explicit and implicit instructions on ESL/EFL learners (Chen, 2009; Maeda, 2011; Aufa, 2012). According to Kasper (1997), "Explicit teaching involved description, explanation, and discussion of the pragmatic feature in addition to input and practice, whereas implicit teaching included input and practice without the metapragmatic component." In other words, explicit instruction should be direct and conscious learning while implicit instruction is indirect and unconscious learning.

Moreover, even advanced EFL learners need to be taught pragmatic speech acts, because they might be in advanced level but still are not able to use the target language properly. Numerous studies concerning the learners' high level of grammatical proficiency have been conducted and indicated that the high grammatical proficiency students will not necessarily have a similar pragmatic competence (Bouton, 1996; Kasper 1997). In another word, even when the levels 
of students are high such as advanced learners, they still may use the speech acts of pragmatics inappropriately that differ from foreign language of pragmatic norms. For this reason, they should be taught pragmatics and assist them improve their pragmatic competence.

Most of the previous studies of Iraqi Kurdish language have concentrated on linguistic fields like, morphology, phonology, phonetics, semantics and syntax. Some other fresh studies, such as Hasan (2014) who focused on Iraqi Kurdish apology strategies. Tahir and Pandian (2016) in a comparison study showed the differences and similarities between Iraqi Kurdish and English Native in using apology strategies in both languages. Unfortunately, researchers have not drawn attention on Iraqi Kurdish EFL learners' pragmatic development through explicit and implicit instructions and it has been largely neglected in foreign language classrooms. The current study is considered as a fresh study that can determine what has been missing in the field of teaching explicit and implicit instructions of pragmatic knowledge.

\section{MEthodology}

The aim of this study is to investigate the effectiveness of explicit and implicit instructions of pragmatic knowledge on the development of advanced EFL learners' apology speech act, to find if there are any significant difference between explicit and implicit groups in terms of apology speech act of pragmatic knowledge after the treatment in posttest and delayed-test, and to see if explicit and implicit instructions of apology speech act facilitate EFL learners' pragmatic knowledge development. In addition, to find the similarities and differences in making the most appropriate apology speech act of pragmatic knowledge between explicit group and implicit group before and after the study. 10 native speakers of English participated in this study and 40 advance students of grade 12 (male and female) were selected from (British International School) in Erbil/Iraq. The participants were provided an Oxford Quick Placement Test (OQPT) proficiency test. The aim was to make sure they were homogeneous in terms of language proficiency and only "Advanced" students were required for this study. 40 students were advance learners who were selected for this study and were randomly divided into two groups; explicit group (EG) and implicit group (IG). Later, the participants of both groups were provided a Background Information Questionnaire to collect necessary information about the students such as; their name and surname, gender, age ...etc. before the treatment.

Then, (IG) and (IG) were both provided a pre-test called Multiple-choice Discourse Completion Test (MDCT) which was taken from Birjandi and Rezaei (2010). The (MDCT) is a written questionnaire which consists of 10 apology situations, each question has 3 different options that are related to the question and it took approximately 40 minutes. The participants were asked to choose a response to each situation that they believed was appropriate in the provided context. The aim of this test was to test the participants' pragmatic knowledge in terms of apology speech act before they start receiving explicit and implicit instructions of apology strategies. For two weeks, (IG) received implicit instruction and (EG) received explicit instruction through teaching them different apology strategies which was adapted from Olshtain and Cohen (1983) classification. In addition, they were both provided different materials such as; computer. speakers, date show, apology exercises, pictures, short videos and short parts of movies were used for both groups but with different instructions of explicit and implicit depending on the groups.

At the beginning of each lesson, (EG) received warm-up activities at the beginning on each lesson regarding the apology strategies they were taught on that lesson by the tutor to drag their attention.

At the end of the sixth session, both groups of (IG) and (EG) were provided the same (MDCT) that was given in pretest as post-test. The aim was to show the learners' development of pragmatic knowledge after receiving pragmatic instructions of explicit and implicit in terms of apology speech act. Then, for two weeks both groups of (IG) and (EG) did not receive any further information on apology speech act, but after these two weeks they were provided the same (MDCT) as a delayed-test to measure their retained knowledge and to see if they still could remember those different strategies they have been taught implicitly and explicitly.

In addition, 10 English native speakers participated in this study who were English teachers and had experience in Teaching. They were given a Multiple-choice Discourse Completion Test (MDCT) and were asked to choose one appropriate answer that they believed is the best as a native speaker for each situation they read. The aim was to collect their data and later compare the answers of the (IG) and (EG) with the answers of the native speakers of English to investigate the participants' appropriateness in terms of apology speech act before and after the study.

Regarding the data analysis, a quantitative discourse analysis approach was adopted to compare the participants' answers of explicit group and implicit group in the pre-test, post-test and delayed-test by teaching them pragmatic knowledge of apology speech act explicitly/ implicitly so as to develop EFL learners' pragmatic knowledge. For this reason, first a t-test was conducted to assure that both groups were homogenous in the knowledge they have concerning pragmatics of apology speech act. Later, a repeated measure ANOVA was conducted to compare advanced EFL learners' Multiple-choice Discourse Completion Tasks (MDCT) in pre-test, post-test and delayed-test.

\section{RESULTS AND ANALYSIS}

To test the research questions of this study, first an independent samples t-test was implemented to assure the homogeneity of pragmatic knowledge in terms of apology speech act before the study. An independent-samples t-test 
was conducted to compare (MDCT) in pre- test between explicit group and implicit group in terms of apology speech act. The results showed that there was not any significant difference $(\mathrm{t}(38)=-0.224, \mathrm{p}=.824)$ between explicit group $(\mathrm{M}=5.75, \mathrm{SD}=0.716)$ and implicit group $(\mathrm{M}=5.8, \mathrm{SD}=0.696)$. This approves that the pragmatic proficiency of both $\mathrm{EG}$ and IG before the treatment was at the same level.

Next, a repeated measures ANOVA was conducted to compare advanced EFL learners' MDCT. A total of 40 EFL students were randomized to receive either explicit instruction or implicit instruction. The explicit group received explicit instruction of apology speech act and implicit group received implicit instruction of apology speech act. The MDCT was measured at pre-test, post-test and delayed-test. Complete data was available at all time points for 20 students who received explicit instruction and 20 students who received implicit instruction. Table 1 shows Mauchly's test indicated that the assumption of Sphericity had been met (Mauchly’s W test statistic $=.920, \mathrm{df}=2 ; \mathrm{p}>.05$ ).

TABLE 1:

MAUCHLY'S TEST OF SPHERICITY

\begin{tabular}{lllll}
\hline Within Subjects Effect & Mauchly's W & Approx. Chi-Square & df & Sig. \\
\hline Time (or Tests) & 0.920 & 3.078 & 2 & 0.215 \\
\hline
\end{tabular}

While Sphericity assumption was met then Sphericity assumed tests are reported on Tests of Within-Subjects Effects as shown in Table 2.

TABLE 2:

TESTS OF WITHIN-SUBJECTS EFFECTS WHEN SPHERICITY ASSUMED

\begin{tabular}{llllll}
\hline Source & Type III Sum of Squares & df & Mean Square & F & Sig. \\
\hline Time & 317.217 & 2 & 158.608 & 377.876 & .000 \\
Time * Groups & 5.550 & 2 & 2.775 & 6.611 & .002 \\
Error (Time) & 31.900 & 76 & .420 & & \\
\hline \multicolumn{7}{r}{}
\end{tabular}

There was a significant main effect time $(\mathrm{F}(2,76)=377.88, \mathrm{P}<0.001)$ which mean there is a significant difference at least between two of the MDCT measurement tests (pre-test, post-test and delayed-test). There was a significant interaction between time and group $(\mathrm{F}(2,76)=6.61, \mathrm{P}<0.01)$. Since the interaction is significant, interpreting the main effects will not lead to an accurate understanding of the results, therefor just focusing on the interaction part is more accurate. Meanwhile, it is necessary to breakdown comparisons between groups for the test levels as it is shown in Table 3. Post hoc comparisons indicated that that there was no difference between the two groups at pre-test $(\mathrm{P}=0.824)$. But significant differences could be found between the EG and IG at post-test and delayed-test, with Explicit group having higher MDCT levels (or Scores) than the Implicit group ( $\mathrm{P}=0.004$ and $\mathrm{P}=0.001$ respectively).

TABLE 3:

PAIRWISE COMPARISONS

\begin{tabular}{|c|c|c|c|c|}
\hline \multirow[b]{2}{*}{ Time Point } & \multirow{2}{*}{$\begin{array}{l}\text { Implicit Group } \\
\text { MDCT Mean(SE) } \\
n=20\end{array}$} & \multirow{2}{*}{$\begin{array}{l}\text { Explicit Group } \\
\text { MDCT Mean(SE) } \\
n=20\end{array}$} & \multirow[b]{2}{*}{$\begin{array}{l}\text { Mean Difference } \\
(95 \% \mathrm{CI})\end{array}$} & \multirow[b]{2}{*}{ P Value } \\
\hline & & & & \\
\hline Pre-test & $5.80(0.158)$ & $5.75(0.157)$ & $-0.50(-0.50,0.40)$ & 0.824 \\
\hline Post-test & $9.10(0.127)$ & $9.65(0.127)$ & $0.55(0.19,0.92)$ & 0.004 \\
\hline Delayed-test & $8.55(0.177)$ & $9.55(0.177)$ & $1.00(0.49,1.51)$ & 0.001 \\
\hline
\end{tabular}

Figure 1 shows clearly the mean of MDCT between explicit group and implicit group in pre-test, post-test and delayed-test. This result is in line with finding of Maeda (2011) where the effectiveness of explicit and implicit teaching was examined by using "Please" request strategies, the aim was to see how far these two teaching approaches impact the understanding of learners' pragmatic. The findings proved that explicit teaching group was significant over implicit teaching group. 


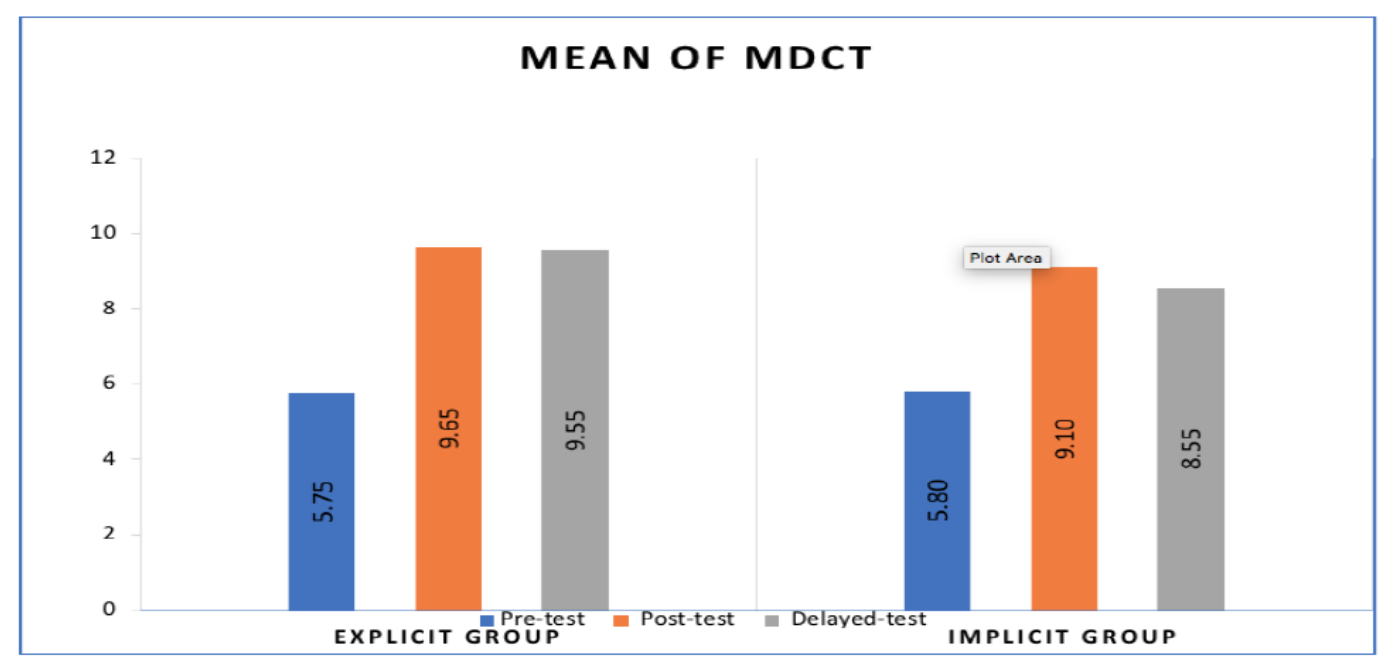

Figure 1: Mean of MDCT

In conclusion, by comparing the $95 \%$ confidence intervals, it can clearly be seen that there is no significant difference between EG and IG in pre-test but the mean values are significantly different for the two groups at both posttest and delayed-test with explicit group having greater progress than implicit group in post-test and delayed-test. This result is similar to the finding of Ghaedrahmat, Nia and Biria (2016) who explored explicit and implicit pragmatic instructions of "Thanking" speech act on EFL learners' pragmatic awareness. The result of their study proved that the participants who were taught thanking speech act explicitly outperformed those ones who were taught implicitly.. Figure 2 shows the Estimated Marginal Means of MDCT.

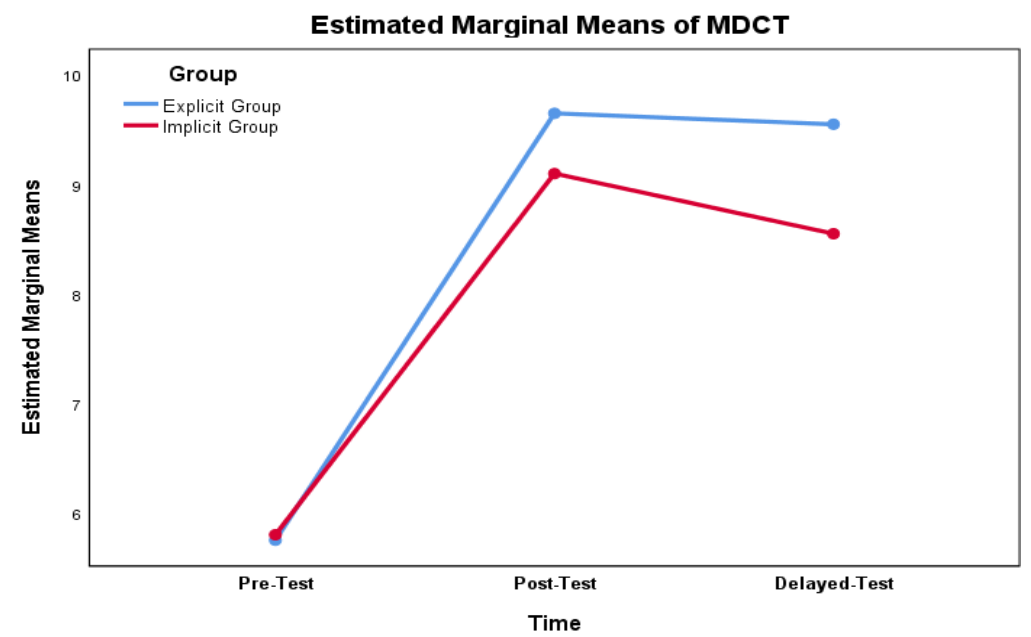

Figure 2: Estimated Marginal Means of MDCT

The result of this study does not hold true with that of Fukuya and Clark (2001), who used a method of input enhancement to draw EFL learners' attention on speech act's target form. The participants of explicit group were provided explicit instruction on sociopragmatic features of request "mitigators" and the participants of the implicit group received the request "mitigator" enhancements. The results showed that there were not any significant differences between both groups of EFL learners' pragmatic knowledge. The findings of the current study indicated that, the results of explicit group and implicit group were significant and they showed improvements in the post-test of MDCT after the treatment, however the explicit group showed greater progress in using appropriate apology strategies than implicit group. While in delayed-test the findings showed that, the results of both groups were significant but an important point could be noticed that explicit group stayed at the same level as they did in the post-test meanwhile implicit group decreased comparing to how their results were in post-test. Therefore, the results indicated that, although the participants were advanced EFL learners but still did not have enough information on giving the best appropriate apology answer before the treatment. But when they were provided pragmatic instructions either explicitly or implicitly, learners became more accurate in terms of apologizing appropriately in different situations. Especially, explicit group which showed a greater progress in post-test and delayed-test. As a result, explicit and implicit instructions of apology speech act facilitative to develop advanced EFL learners' pragmatic knowledge of apology speech act. However, 
explicit instruction of pragmatic knowledge is more facilitative than implicit instruction to develop advanced EFL learners' pragmatic knowledge.

Furthermore, similarities and differences could be found between IG and EG before and after the study. Both groups, for each appropriate answer as native speakers did, the participants received 1 point and if the whole answers were correct, they received 10 points $(\% 100)$. The number of the participants were 20 students in each group, and for example when the participants of explicit or implicit groups answered one of the given situations of the MDCT correctly, they got $(20=100 \%)$ as an appropriate answer, that means each student has got one point in that group and in that specific given situation as shown in Table 4.

TABLE 4:

TOTAL OF MDCT FOR BOTH GROUPS

\begin{tabular}{|c|c|c|c|c|c|c|c|c|c|c|c|c|}
\hline Groups & \multicolumn{6}{|c|}{ Explicit } & \multicolumn{6}{|c|}{ Implicit } \\
\hline Situations & \multicolumn{2}{|c|}{ Pre-test } & \multicolumn{2}{|c|}{ Post-test } & \multicolumn{2}{|c|}{ Delay-test } & \multicolumn{2}{|c|}{ Pre-test } & \multicolumn{2}{|c|}{ Post-test } & \multicolumn{2}{|c|}{ Delay-test } \\
\hline S1 & 12 & $60 \%$ & 20 & $100 \%$ & 19 & $95 \%$ & 12 & $60 \%$ & 18 & $90 \%$ & 17 & $85 \%$ \\
\hline $\mathrm{S} 2$ & 13 & $65 \%$ & 19 & $95 \%$ & 19 & $95 \%$ & 12 & $60 \%$ & 20 & $100 \%$ & 18 & $90 \%$ \\
\hline S3 & 9 & $45 \%$ & 18 & $90 \%$ & 18 & $90 \%$ & 10 & $50 \%$ & 15 & $75 \%$ & 16 & $80 \%$ \\
\hline S4 & 12 & $60 \%$ & 19 & $95 \%$ & 19 & $95 \%$ & 12 & $60 \%$ & 19 & $95 \%$ & 17 & $85 \%$ \\
\hline S5 & 13 & $65 \%$ & 20 & $100 \%$ & 20 & $100 \%$ & 13 & $65 \%$ & 19 & $95 \%$ & 19 & $95 \%$ \\
\hline S6 & 12 & $60 \%$ & 19 & $95 \%$ & 20 & $100 \%$ & 12 & $60 \%$ & 18 & $90 \%$ & 17 & $85 \%$ \\
\hline S7 & 12 & $60 \%$ & 19 & $95 \%$ & 20 & $100 \%$ & 11 & $55 \%$ & 18 & $90 \%$ & 16 & $80 \%$ \\
\hline S8 & 11 & $55 \%$ & 19 & $95 \%$ & 18 & $90 \%$ & 11 & $55 \%$ & 17 & $85 \%$ & 17 & $85 \%$ \\
\hline S9 & 10 & $50 \%$ & 20 & $100 \%$ & 18 & $90 \%$ & 11 & $55 \%$ & 19 & $95 \%$ & 16 & $80 \%$ \\
\hline $\mathrm{S} 10$ & 11 & $55 \%$ & 20 & $100 \%$ & 20 & $100 \%$ & 12 & $60 \%$ & 19 & $95 \%$ & 18 & $90 \%$ \\
\hline
\end{tabular}

In addition, the answers of both groups were compared to how English native speakers chose the most appropriate answers in the given situations. In pre-test both groups of IG and EG had problem in situation 3. Later, they were both improved in post-test, implicit group moved from (50\%) to $(75 \%)$ meanwhile explicit group moved from $(45 \%)$ to $(90 \%)$. In terms of choosing the most appropriate apology exactly as how English native speakers use them in post-test, implicit groups' highest level was in situation 2 which was (100\%). Meanwhile, in explicit group was in situation 1,5,9 and 10 which was (100\%). Moreover, the results of delayed-test showed that, implicit group's highest progress of choosing the best appropriate answer was in situation 5 where they had (100\%). Whereas, explicit group's highest progress was in situation 5, 6,7,9 and 10 which was (100\%) as shown is Table 4. This indicates that, both groups' pragmatic knowledge was developed with explicit group outperforming implicit group as shown in Figure 2.

\section{DisCUSSIONS AND CONCLUSIONS}

For the last decade a lot of studies have been conducted in various countries and languages regarding the role of instructions in the development of pragmatic knowledge. In spite of that, very few studies have shed light on the use of pragmatic speech acts so as to develop Iraqi Kurdish EFL learners' pragmatic knowledge. For example, Tahir and Pandian (2016) used a DCT to find differences and similarities between EFL Kurdish learners and American native speaker. Furthermore, Hasan (2014) focused on Iraqi Kurdish apology strategies to illustrate the politeness of Kurdish culture from a socio-pragmatic situation with regard to obligation to apologies. Moreover, Tahir and Pandian (2016) compared Iraqi Kurdish learners and English Native speakers' apology strategies to find the differences and similarities between these two languages. Hence, this study is considered as a fresh study which has shed light on the use of explicit and implicit instructions on the development of pragmatic knowledge of advanced Kurdish EFL learners' apology speech act. The finding of this research can be used as a starting point information for further studies.

The main finding of the current study is that explicit instruction is better than implicit instruction for teaching English apology speech act. The finding is strongly agreed upon other scholars' works such as Xiao-le (2011) who explored the effectiveness of explicit and implicit Instructions of "Request Strategies" on gaining pragmatic knowledge of Chinese EFL learners. The results indicated that explicit group had greater progress in the appropriate level of being polite, using formal and direct situations than implicit group. Similar finding is reported in, Kia and Salehi (2013) who showed the instructional strategies of explicit and implicit teaching on the development EFL learners' pragmatic knowledge by selecting "Thanking and Compliment" speech acts. The results revealed that explicit teaching outperformed the implicit teaching. It can be suggested that, explicit instruction is a very clear teaching method, more way of saying effective, direct, stress-free technique that helps learners understand and learn without making them tired or feel bored.

However, we also should not ignore the fact that implicit instruction is also helpful in developing advanced EFL learners' pragmatic knowledge but, implicit instruction is not as effective as explicit instruction because explicit instruction of pragmatic knowledge is more helpful to understand apology speech act comparing to implicit instruction as EFL learners be aware of pragmatics as well as to develop the advanced learners' pragmatics in choosing the most appropriate apology strategies and form that can be similar to native English speakers in different situations.

Regarding explicit and implicit instructions of teaching pragmatic, the results of this study indicated that pragmatic can be taught in EFL classroom and with the grammatical knowledge pragmatics should be taught. In addition, advanced EFL learners were preferred to participate in this study because they have a high level of grammatical proficiency and have information about apologizing as was shown in the pre-test, but this is not enough and still they 
could not use apology speech act appropriately. This shows the fact that, even advanced learners needed to be exposed to the various strategies, categories and sub-categories of apology speech act to use appropriate pragmatic as well as to assist them in developing their knowledge of pragmatics. This comes in line with (Bouton, 1996; Kasper 1997) who believed that the high grammatical proficiency students will not necessarily have a similar pragmatic knowledge.

\section{APPENDICES}

Appendix 1: Oxford Quick Placement Test (OQPT)

Appendix 2: Background Information

Appendix 3: Multiple-choice Discourse Completion Test (MDCT) for pre-test, post-test \& delayed test

Appendix 4: Exercises on apology strategies in different sessions

Appendix 5: Pictures on apology strategies in different sessions

Appendix 6: Ethical Approval Form

\section{ACKNOWLEDGEMENTS}

I would like to express my sincere gratitude to my advisor Asst. Prof. Dr. AKBAR RAHIMİ ALISHAH for the continuous support of my M.A study and research, for his patience, motivation, and immense knowledge. His guidance assisted me in writing this thesis. Likewise, my sincere gratitude goes to Prof. Dr. TÜRKAY BULUT the head of English language and literature department, for her encouragement.

I would also like to thank Mr. Kevin Tubb, the manager of British International School in Erbil and the students, who have willingly shared their precious time during the preparation of this thesis. In addition, my sincere thanks are to my loved ones, who have supported and motivated me throughout the entire process, I really appreciate it.

Finally, I must express my very profound gratitude to my family for providing me with unfailing support and continuous encouragement throughout my years of study and through the process of researching and writing this thesis. This accomplishment would not have been possible without them. Thank you.

\section{REFERENCES}

[1] Aufa, F. (2012). The Assessment Tool of L2 Learners' Pragmatic Competence: Written Discourse Completion Test (WDCT). International Proceedings of Economics Development \& Research, 6(1), 24-31.

[2] Bataineh, R. F. \& Bataineh, R. F. (2006). Apology strategies of Jordanian EFL university students. Journal of Pragmatics, 38(11), 1901-1927.

[3] Birjandi, P. \& Rezaei, S. (2010). Developing a multiple-choice discourse completion test of interlanguage pragmatics for Iranian EFL learners. ILI Language Teaching Journal (Special Issue: Proceedings of the First Conference on ELT in the Islamic World), $6(1,2), 43-58$.

[4] Blum-Kulka, S., House, J., \& Kasper, G. (1989). Cross-cultural pragmatics: Requests and apologies. Norwood, NJ: Ablex Pub. Studies in Second Language Acquisition. 14(2), 217-218.

[5] Bouton, L. F. (1996). Pragmatics and language learning. In L. F. Bouton (Ed.), Pragmatics and Language Learning, monograph series vol. 7 (pp. 1-30). Urbana-Champaign, IL: Division of English as an International Language, University of Illinois, Urbana-Champaign.

[6] Cambridge Online Dictionary. (2017). Apology Meaning in the Cambridge English Dictionary. [online] Dictionary.cambridge.org. Available at: https://dictionary.cambridge.org/dictionary/english/apology [Accessed 30 Nov. 2017].

[7] Chen, Y. (2009). Learner Perceptions of Instruction in L2 Pragmatics. English Language Teaching, 2(4), 154-161.

[8] Dastjerdi. H.V., \& Rezvani. E. (2010). The impact of instruction on Iranian intermediate EFL learners' production of requests in English. Journal of Language Teaching and Research, 1(6), 782-790.

[9] Fukuya, Y., \& Clark, M. (2001). A comparison of input enhancement and explicit instruction of mitigators. In L. Bouton (Ed.), Pragmatics and language learning (pp. 111-130). Chicago: Division of English as an International Language, University of Illinois at Urbana-Champaign.

[10] Ghaedrahmat, M., Nia, P.A. and Biria, R. (2016). The effect of explicit vs. implicit instruction on mastering the speech act of thanking among Iranian male and female EFL learners. Latin American Journal of Content \& Language Integrated Learning, $9(2), 401-425$.

[11] Hassan, F.A. (2014). Apology Strategies in Central Kurdish with Reference to English: An Empirical Study in SocioPragmatics (Doctoral dissertation, Prifysgol Bangor University).

[12] Kasper, G. (1997). Can pragmatic competence be taught? Second Language Teaching and Curriculum Center, 3(2), 1-19

[13] Kia, E. and Salehi, M. (2013). The effect of explicit and implicit instruction of English thanking and complimenting formulas on developing pragmatic competence of Iranian EFL upper-intermediate level learners. Journal of Basic and Applied Scientific Research, 3(8), pp.202-215.

[14] Maeda, S. (2011). A Study of implicit teaching and explicit teaching of the usage of "Please" to high school students. In The 16th Conference of Pan-Pacific Association of Applied Linguistics (pp. 436-443).

[15] Malaz, I., Rabiee, M., \& Ketabi, S. (2011). The pragmatic instruction effects on Persian EFL learners' noticing and learning outcomes in request forms. Journal of Technology \&Education, 5(3), 187-193.

[16] Olshtain, E. \& Cohen, A. (1983). Apology: A speech act set. Sociolinguistics and language acquisition, pp.18-35. In N. Wolfson, \& E. Judd (Eds.), Sociolinguistics and language acquisition (pp. 18-36). Rowley, MA: Newbury House.

[17] Rose, K.R. and Ng Kwai-Fun, C. (2001). Inductive and deductive teaching of compliments and compliment responses. In K. R. 
Rose, G. Kasper (Eds.), Pragmatics in language teaching (pp. 145-170). Cambridge, UK: Cambridge University Press.

[18] Sadeghi, A., Foutooh, M. (2012). The effect of explicit instruction of compliment responses strategies on intermediate Iranian foreign language learners' ability to respond to compliments. International Journal of Linguistics, 4(3), 385-406.

[19] Tahir, R. \& Pandian, A. (2016). A comparative Analysis of apology Speech acts between American English and Iraqi Kurdish. Malaysia. IJELLH (International Journal of English Language, Literature in Humanities). Volume 4. Issue 7. 249-267.

[20] UCLES Placement Test | Christopher Columbus - Scribd. Oxford Quick Placement Test. Available at: https://www.scribd.com/document/208335904/UCLES-Placement-Test. [Accessed 15 September. 2017].

[21] Xiao-le, G.U. (2011). The Effect of Explicit and Implicit Instructions of Request Strategies. Intercultural Communication Studies, 20(1), 104-123.

Pasand Shark was born and raised in Erbil/ Kurdistan the region of Iraq. After graduation from Salahaddin University, she became an English Teacher at Britannia Educational Services (Cambridge College) in Erbil and later became Cambridge KET and Cambridge YLE Examiner. Two years later, she travelled to Germany and took German lessons at Projekt Deutsch Lernen in Dortmund. Next, she earned her Master's degree in English Language and Literature from Istanbul Aydin University. During her Master studies, she took Turkish lessons and worked as a translator at the Syndicate of Accountants in Erbil (from Kurdish-Arabic to English and vice versa). She is planning to continue studying at one of the best European countries and earn PhD degree.

Bachelor: 2011, Salahaddin University, College of Education, English Department.

Master: 2018, Istanbul Aydin University, Faculty of Arts and Sciences, English Language and Literature. 